\title{
Comparative analysis of local taxation in Kazakhstan and Turkey
}

\author{
Manet Nurmaganbetova ${ }^{1, *}$ \\ ${ }^{1}$ Kazakh-Russian International University, 30006, 52 Aiteke bi str., Aktobe, Kazakhstan
}

\begin{abstract}
Return of duties matter in regions local budgets of Kazakhstan is considered in this article. The important role and value of local budgets, which may be considered a financial base of many-sided activity of local authority bodies and management, is reviewed in the paper, as well as the problems of local budgets in Kazakhstan. On the basis of statistical data on the dynamics of tax revenues, the budget of Kazakhstan is analyzed, along with the role of local taxes in regions' budgeting of Kazakhstan. Special emphasis is given to the theory of fiscal federalism. I also review the international experience of the local taxation on the example of Turkey, focusing on Kazakhstan and Turkish experience of national income redistribution through the budget, as well as relying on the Aktyubinsk region as a case study for budget implementation. On the basis of the conducted research problems of local budgeting, I reveal the redistributions of receipts through the republican budget. The author has drawn conclusion that the level of tax revenues and tax capacity of the region significantly influence opportunities and quality of economic growth of the region. The author suggests that budgeting of all levels has to be based on the scientific forecast of revenues of the budget, develop technique of forecasting profitable opportunities of local budgets.
\end{abstract}

\section{Introduction}

Local taxes are the main method of mobilizing financial resources in local budgets, since their share in the revenues of local authorities of developed countries accounts for a high percentage of all tax revenues. Their revenues are used to finance the development of transport, construction of schools, hospitals, other infrastructure, as well as costs of urban reconstruction, improvement of roads, etc., which indicates their important role in the social and economic development of local areas.

Existence of local taxation system meets certain interests of local executive bodies as they are stable and independent source of the income of local budgets. At the same time, performance of a number of nation-wide social tasks is impossible without attracting local finance in the form of tax. Thus, the important role of local taxes and fees is that they

\footnotetext{
* Corresponding author: manet.67@ mail.ru
} 
guarantee financial support of various programs, which are certainly important for regions. These statements also cause relevance of our research [1].

In the Republic of Kazakhstan, local taxes are the basis of local budgeting. In the conditions of market economy, the creation of a perfect and effective system of the local taxation promoting sustainable development and effective accumulation of means of the state budget is actual [2].

\section{Problem Statement}

The problems of collection of local taxes which are available today directly influence dynamics of statistical data in formation of tax revenues in the budget. The issue of redistribution of receipts through the republican budget by means of the mechanism of the budgetary withdrawals and subventions also is actual, that is developing this mechanism on the objective beginnings is required.

Now problems of local budgets in Kazakhstan are also caused by the fact that the branches of economy making their property do not yield revenues for budgeting, but are unprofitable and absorb considerable part of means of local budgets. At division of property on republican and municipal levels, local authorities have been given the unprofitable enterprises or those that bring small income.

\section{Research Questions}

In the course of the study, the role and value of local taxes and fees in territorial budgeting have been carefully researched, questions of return of duties in local budgets of regions of Kazakhstan are investigated, the experience of the local taxation on the example of Turkey is studied, and the analysis of budget implementation of the Aktyubinsk region is carried out. Materials of research are the economic relations on ensuring local budgeting.

\section{Purpose of the Study}

The research objective is to study the role of local taxes in local budgeting. The comparative analysis of the local taxation on the example of Turkey and Kazakhstan and the development of suggestions for improving the mechanism of the budgetary forecasting on the basis of indicator of tax potential is conducted.

\section{Research Methods}

Scientific research of domestic and foreign scholars and also of the experts in the field of taxation and legislation of the Government in Republic of Kazakhstan have formed the theoretical and methodological basis of research.

During processing, studying, and analysis of the materials by the complex of methods of economic research, we used a united systemic approach to studying this problem has been used. At different stages of work analytical, graphic, economical and statistical, abstract and logical, comparative methods of research, with their diverse ways and receptions were applied.

\section{Findings}


By establishing local taxes, representative bodies of local self-government determine the following elements of taxation in the regulatory legal acts: tax rate within the limits established by the Tax Code, procedure and terms of tax payment, tax privileges in the order and limits provided by the Tax Code.

Local taxes in the Republic of Kazakhstan include: (1) an individual income tax; (2) a social tax; (3) a tax on vehicles; (4) a property tax; (5) a land tax; (6) a unified land tax excises; (7) a fixed tax [3].

For a visual examination of the importance of local taxes in the formation of the local budget, we use the statistical data of the Ministry of Finance in Republic of Kazakhstan for the last 4 years. Let's define dynamics of taxes and other mandatory payments to the budget for the period from 2013 to 2016 based on the data in Table 1 .

Table 1. Indicators of local taxes in the formation of the local budget, million tenge.

\begin{tabular}{|c|c|c|c|c|c|}
\hline Local budget & 2013 & 2014 & 2015 & 2016 & $\begin{array}{c}2016 \text { to } \\
2013 ., \text { in \% }\end{array}$ \\
\hline Incomes, million tenge & 3284 & 3752 & 3667 & 4315 & 76,1 \\
& 401,0 & 971,1 & 358,6 & 582,5 & \\
\hline Costs, million tenge & 3233 & 3661 & 3606 & 4203 & 76,9 \\
\hline $\begin{array}{c}\text { Budget deficit (surplus), million } \\
\text { tenge }\end{array}$ & -25 & -31 & -76 & -99 & - \\
\hline $\begin{array}{c}\text { Budget deficit (surplus) as a } \\
\text { percentage of GDP }\end{array}$ & $-0,1$ & $-0,1$ & $-0,2$ & $-0,2$ & - \\
\hline
\end{tabular}

In accordance with the data in Table 1, there is an annual increase in the revenues of local taxes in the formation of local budgets. In 2016, the percentage of income was $76.1 \%$ to 2013 , in 2016 , the costs accounted for $76.9 \%$ to 2013 [4].

As the analysis has shown, the indicators of local taxes play a key role in the formation of local budgets of the corresponding levels and in the replenishment of the state budget in Republic of Kazakhstan as a whole.

For today, in the Republic of Kazakhstan, a pressing problem is the declaration of incomes of physical persons, including local taxes. The Resolution of Government of the Republic of Kazakhstan dated September 23, 2010 No. 975 approved the concept of transition to the universal declaration of income and property by citizens of the Republic of Kazakhstan and persons holding a residence permit.

Universal declaration of income in Kazakhstan began in the Republic of Kazakhstan in 2013. The issue of universal declaration is now topical; this process is to be gradually introduced in the next 7 years [5].

To date, given the existing difficulties and shortcomings in the system of formation and replenishment of budgets, it is becoming necessary to find other ways and approaches to the problem of scarcity, in particular, local budgets. First of all, it is necessary to increase the financial independence of the regional and local authorities by increasing the share of their own tax sources in the respective budgets. At the same time, they should be considered as their own only provided that they are permanently assigned to a specific budget, and the relevant authorities have sufficient authority to manage the elements of these revenue sources.

In the annual Address to the people of Kazakhstan "The Strategy 'Kazakhstan - 2050: A New Political Course of Held State" from 2012 by the President of the Republic of Kazakhstan, the leader of the nation N. A. Nazarbayev emphasized the implementation of a 
new tax policy, which has a social orientation. To this end, starting in 2015, a set of incentive measures will be developed, including those that provide for the practice of tax exemptions for companies and citizens investing in education and health insurance for themselves, their families, and employees.

Also, the President of the Republic of Kazakhstan, N. A. Nazarbayev, set the goal of Kazakhstan's entry into the thirty most developed countries of the world tby 2050. To achieve these goals, by establishing the optimal framework for administrative procedures and increasing the transparency of their implementation, the state is actively pursuing measures aimed at reducing the costs of doing business, reducing bureaucratic delays, and corruption for both domestic entrepreneurs and international investors [6].

Thus, summarizing the above, it can be concluded that the existing problems of levying local taxes directly affect the dynamics of statistical data in the formation of tax revenues. To date, the taxation in Kazakhstan is given due attention. In this regard, there is a set of measures to improve the tax system and local taxes in particular. As a result, it is planned that the improvement mechanism will focus on the effectiveness of local tax collection in the Republic of Kazakhstan.

After a protracted recession in 2015 , the volume of tax revenues to the budget of Kazakhstan is restored: in annual terms, the growth of fees exceeded $37 \%$. Over the seven months of 2016, the state budget has been replenished for more than 3 trillion tenge.

The dynamics of revenues to the state budget of Kazakhstan has taken a positive direction for the first time since 2015: for 7 months of this year, the budget received 3.2 billion tenge, while for the same period 2015 only 2.3 trillion tenge were collected. At the same time, in 2015, it was raised by 231.8 billion tenge less than in 2014 (Fig. 1).

The main source of growth was taxes on goods and services, including excises and VAT: their fees increased by $33.5 \%$ or by 467.3 billion tenge in annual terms. Corporate income tax levied on companies in the non-oil sector increased by almost a quarter, by 192.2 billion tenge $(+24.1 \%)$.

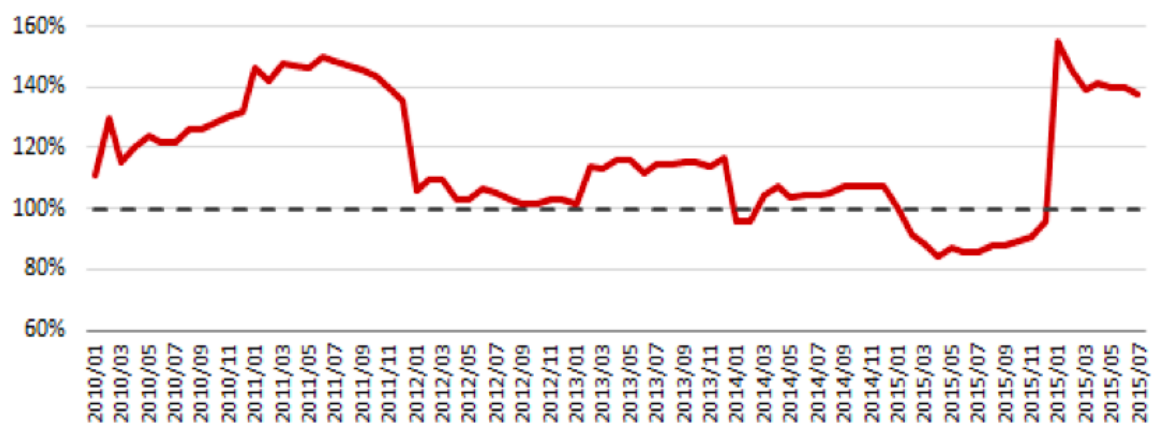

Fig. 1. The index of growth of tax revenues to the budget of the Republic of Kazakhstan, 2010-2016 [7].

Simultaneously with the increase in the amount of taxes collected for replenishment of the budget, taxes received by the National Fund from oil companies show a rapid decline in volumes. And if earlier revenues to the National Fund were $74.2 \%$ and $42.8 \%$ for the seven months of 2014 and 2015 respectively, they did not exceed $20 \%$ in 2016, primarily due to a drop in crude oil prices by an average of $47.5 \%$ compared to previous periods (Fig. 2). 


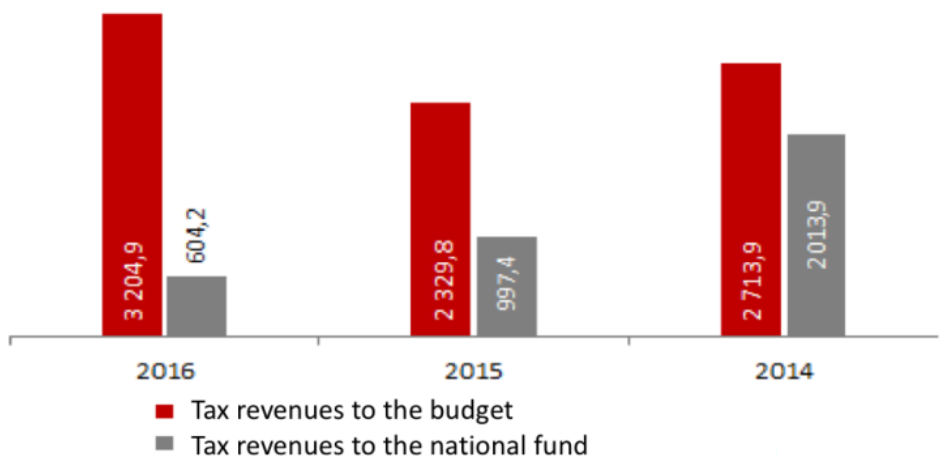

Fig. 2. Ratio of revenues to the budget and the National Fund [7].

Even without taking into account the "oil" taxes after the capital cities, the oilproducing the Atyrau and Mangistau regions are the leaders in raising funds for the state budget, while the five leaders are closest to the first-largest region of Kazakhstan - the South Kazakhstan region. It is noteworthy that the State Revenue Committee, responsible for collecting taxes in the field of international trade, was among the top three leaders in increasing the volume of tax collections in 2016, skipping ahead the East Kazakhstan and Atyrau oblasts (table 2).

Table 2. Volumes of tax revenues, regions of the Republic of Kazakhstan, 2016 (bln tenge).

\begin{tabular}{|c|c|c|c|c|c|c|}
\hline \multirow{2}{*}{ Country } & \multicolumn{2}{|c|}{ Revenues } & \multicolumn{2}{c|}{ Growth to total } & \multicolumn{2}{c|}{ Share from RK } \\
\cline { 2 - 7 } & 2016 & 2015 & \multicolumn{2}{|c|}{2015} & 2016 & 2015 \\
\hline Kazakhstan & 3204,9 & 2329,8 & $37,6 \%$ & 875,1 & $100,0 \%$ & $100,0 \%$ \\
\hline Almaty & 846,0 & 650,3 & $30,1 \%$ & 195,7 & $26,4 \%$ & 27,9 \\
\hline Astana & 457,8 & 332,8 & $37,6 \%$ & 125,0 & $14,3 \%$ & $14,3 \%$ \\
\hline Atyrau & 438,9 & 207,5 & $111,5 \%$ & 231,4 & $13,7 \%$ & $8,9 \%$ \\
\hline Mangistau & 172,5 & 152,8 & $12,9 \%$ & 19,7 & $5,4 \%$ & $6,6 \%$ \\
\hline SKO & 164,6 & 107,1 & $53,7 \%$ & 57,5 & $5,1 \%$ & $4,6 \%$ \\
\hline Aktobe & 140,0 & 101,8 & $37,5 \%$ & 38,2 & $4,4 \%$ & $4,4 \%$ \\
\hline WKO & 134,4 & 104,5 & $28,6 \%$ & 29,9 & $4,2 \%$ & $4,5 \%$ \\
\hline Almaty & 133,4 & 132,4 & $0,7 \%$ & 1,0 & $4,2 \%$ & $5,7 \%$ \\
\hline EKO & 124,5 & 77,0 & $6,8 \%$ & 47,6 & $3,9 \%$ & $3,3 \%$ \\
\hline KGD MF RK & 123,0 & 76,9 & $59,9 \%$ & 46,1 & $3,8 \%$ & $3,3 \%$ \\
\hline Pavlodar & 118,5 & 81,5 & $45,5 \%$ & 37,1 & $3,7 \%$ & $3,5 \%$ \\
\hline Karaganda & 117,6 & 114,4 & $2,8 \%$ & $3,2 \%$ & $3,7 \%$ & $4,9 \%$ \\
\hline Kostanay & 65,2 & 51,3 & $27,1 \%$ & 13,9 & $2,0 \%$ & $2,2 \%$ \\
\hline Akmola & 54,2 & 41,1 & $32,0 \%$ & 13,1 & $1,7 \%$ & $1,8 \%$ \\
\hline Kyzylorda & 43,8 & 36,5 & $20,1 \%$ & 7,3 & $1,4 \%$ & $1,6 \%$ \\
\hline Zhambyl & 37,4 & 31,4 & $19,1 \%$ & 6,0 & $1,2 \%$ & $1,3 \%$ \\
\hline NKO & 33,0 & 30,5 & $8,3 \%$ & 2,5 & $1,0 \%$ & $1,3 \%$ \\
\hline
\end{tabular}

Source: [7].

An important role in local finance belongs to local budgets, which are the financial base for the multifaceted activities of local authorities and management.

Local self-government bodies independently manage the resources of local budgets. In the revenue and expenditure parts of local budgets, it is separately provided for financing the resolution of local issues and the implementation by local governments of individual republican powers.

Local budgets (oblasts, cities, districts) in Kazakhstan are occupied by incomes and expenditures within $50 \%$ of the state budget. 
In the budgetary form of the organization of financial relations, there are two tendencies:

- Centralization of the system of forms and methods of managing the movement of financial resources as a reflection of a more general process of developing the centralized principles in the management of the economy in order to overcome the crisis and stabilization;

- Decentralization of finance with strengthening of functions of local authorities and management in the formation and use of financial funds.

The second trend is justified by the approximate local authorities to local conditions, their greater interest in the socio-economic development of the territories.

The principle of administering financial relations is the ability to exercise the control function of finance: less certain financial relationship is subject to formal control, the more desirable it is to assign it to decentralized regulation, and, conversely, with good control over it, to the centralized regulation.

The world financial theory and practice determine that local budgets function as an independent part of the budget system. The autonomy of the budget is understood as the situation when the regional authority on the basis of a fixed revenue base determines the amount of the budget, the specific structure and the amount of revenues and expenditures by items. Its execution is carried out on the basis of the republican legislation defining the rights in this area of regional government bodies.

On the other hand, regions are parts of a single economic complex that is in certain subordination cannot exist outside of it. The content and nature of regional reproduction are determined by the basic laws of the development of the entire social reproduction. Therefore, the necessity of centralism in management in reasonable limits, conditioned by the real state of production, is assumed. The economic independence of the regions cannot be absolute. It is always relative, and the smaller the region, the less is the measure of this independence, that is, the freedom in making decisions independent of the center.

Moreover, the current level of social and economic development of the regions, the prevailing nature of budgetary relationships, the complexity of the period of transition to a market economy do not allow talking about the real independence of most of the local budgets of the republic. Therefore, the principle of sufficiency of means for financing the social infrastructure should be implemented in a size that ensures a guaranteed minimum of social benefits to the population. The independence of each administrative-economic unit must have some optimal level, the criterion of which is to maximize the realization of the economic interests of the region.

One of the important conditions for the economic independence of the regions is the creation in them of guaranteed sources of funds necessary for financing activities for the reproduction of regional resources, nature protection.

The general principle of determining the optimal combination of centralized and local principles in the management of the region's economy is formulated as follows: centralism in determining the strategy of economic development, independence in its implementation.

Operational and economic independence requires the creation in the local part of a separate, fixed revenue system covering not less than $50 \%$ of expenditure, rigid fixation of revenues over a budget for a long period.

In countries, with developed market economies, the redistribution of national income through the budget is carried out on the basis of the theory of "fiscal federalism".

The essence of the theory is that the entire state economy as a whole (all enterprises, institutions and administrative structures belonging to the public sector of the economy) is a multi-level system where there is a division of management functions between the levels and their legal vertical subordination. In this regard, the focus is on the following issues:

- An optimal number of levels of public sector management; 
- An optimal distribution of powers between levels of management;

- A level of the most effective financing of social expenditures;

- A degree of intervention by the central government in the management and financing of local authorities;

- A share of own funds in financing the costs of local authorities and management;

- A form of control over the expenditure of funds at all levels of the state economy [8].

In Turkey, income taxes are levied on income received both domestically and abroad by individuals and corporations that are residents of Turkey. Non-residents who earn income in Turkey through employment, property, and income-generating businesses are also subject to taxation, but only with income earned in Turkey.

The obligation to pay taxes by individuals relates to: an income-related activity; a trade or entrepreneurial activity, conducted on a permanent basis; to the salary received for work performed in Turkey, to income-related revenues from the real estate in Turkey, to the interest received from Turkey; to income from the sale of patents, copyrights and other various intangible assets. Personal income tax on individuals (income tax) varies from $15 \%$ to $40 \%$.

For tax purposes, companies are grouped into both joint-stock companies and limited liability companies, as well as to personal companies (limited partnerships and simple partnerships). Corporate tax is levied on the above companies.

The state-owned enterprises and organizations under the jurisdiction of local authorities are also corporate tax payers. Whether the company falls under a full or limited duty to pay tax depends on whether the company is a resident of Turkey or not.

A company whose permanent residence or administrative seat is established in Turkey (the resident company) will have a full duty to pay the tax. In this case, the tax is levied on profits received both domestically and abroad. If a company is not a resident who conducts its business through its branch or joint venture, it will have limited duties to pay tax; that is it will be subject to taxation on income received for a certain year in Turkey.

If the company is not present in Turkey, the tax will be deducted from the income received; for example, for services provided in Turkey. However, if there is an agreement on avoidance of double taxation with respect to income taxes, then in this case, reduced rates for withholding tax may be applied.

The basic tax on income of companies doing business in Turkey is $20 \%$ (by Law No. 5520 of July 21, 2006, the corporate income tax was reduced from $30 \%$ to $20 \%$ ) [9]. The tax on dividends received by both Turkish and foreign shareholders is paid at a rate of $10 \%$.

For resident companies, the tax is levied on income received both domestically and abroad, but a loan is granted to pay taxes on income received abroad (up to the corporate income tax rate existing in Turkey, i.e. 20\%).

Corporations are invited to pay the Advance Corporate Tax on income (Advanced Corporate Tax), based on income received quarterly, at a rate of $30 \%$. Advance corporate income tax paid during the tax year is an alternative to the obligation to pay an initial corporate tax on the company's income.

In accordance with the Turkish Commercial Code, Turkish companies are required to form the first and second level legal reserves from the revenues received. This obligation does not apply to company departments).

Joint stock companies and limited liability companies are required to provide $5 \%$ of the net profit to the reserve of the first level every year. The limit of the first level of the legal reserve is $20 \%$ of the paid-up capital. The second level of the legal reserve is $10 \%$ of the profit distributed after the formation of the first level of the legal reserve and the minimum payment of dividends ( $5 \%$ of the paid-up capital).

Regarding the formation of the second level of the legal reserve, there is no limit, and it accumulates every year. 
According to the Commercial Code of Turkey, if legal reserves have reached the level of $50 \%$ of the paid-up capital, they should be used to cover losses or to maintain business activity in the event of deterioration of economic conditions or to prevent unemployment, and also to counter negative consequences, being related to unemployment [10].

As a rule, the corporate income tax is calculated on the basis of a calendar year. However, companies can establish any 12-month fiscal period convenient for running their business, which should be approved by the Ministry of Finance of Turkey. Companies that have their location and administration location outside Turkey but are established in Turkey in the form of a branch are subject to taxation of income received from a permanent organization located in Turkey.

In Kazakhstan, however, the policy of fiscal decentralization is aimed at reducing the financial dependence of local governments on the center. This is the way to reduce the deficit not only of local budgets, but of the state budget as a whole, the way to real independence in solving local social problems. It is achieved through the development of tax autonomy in the regions, granting them the rights to collect local allowances for nationwide taxes or the appointment of their own taxes (environmental, property, inheritance, consumption). At the same time, transfer financing from the central budget is reduced, which does not interest local authorities in the effective use of funds, which deprives them of their financial independence.

In previous years, a large number of functions and powers were transferred from the central to the local level. Now they need to be backed up with sufficient financial independence. At the same time, it is important not to allow the concentration of expenditure responsibilities at the regional level. It should be transferred further to the district and rural levels. Akims should solve issues of regional and local importance, and the Government should concentrate on state-wide issues. So, the execution of the budget of the Aktyubinsk region for 2016 is as follows (Figure 3).

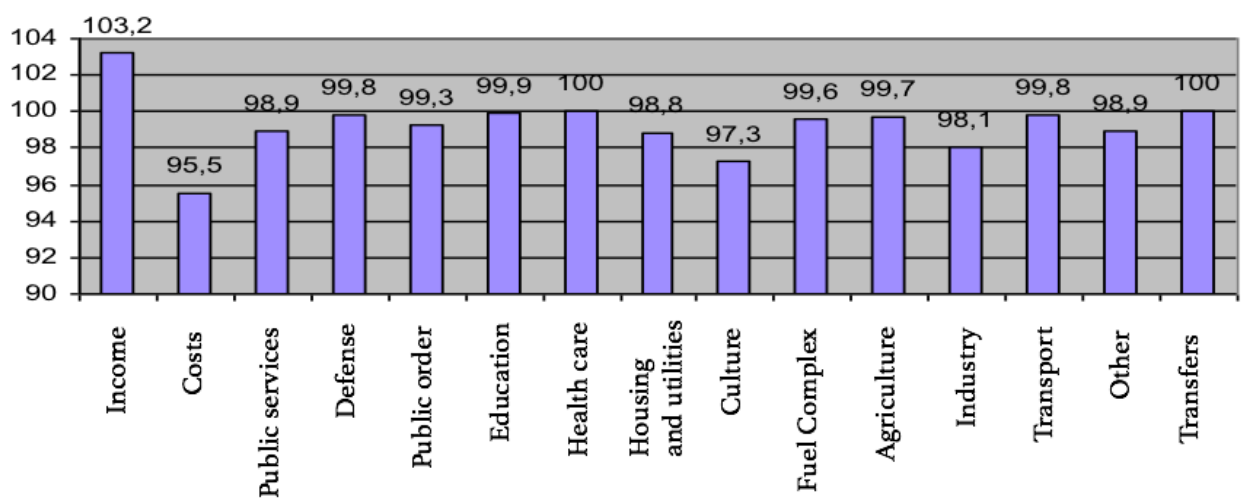

Fig. 3. Budget execution of Aktyubinsk region for 2016, \%. Note. Source - www.aktobe.gov.kz [11].

Incomes: taking into account the revenues of transfers from the republican budget, the budget of the Aktyubinsk region was fulfilled by $103.3 \%$. At the plan of 175746704,1 thousand tenge, the cash execution has made 181473608,0 thousand tenge.

Expenses: taking into account transfers, the development amounted to $99.5 \%$. At the plan of 195304830,1 it is mastered 194283 609,6 thousand tenge. As of January 1, 2017, special transfers to the lower budget have been allocated from the regional budget in the amount of $65,717,738.2$ thousand tenge [11].

The expenditures of local budget are dominated by financing social infrastructure education, health, social protection of the population, from economic sectors - transport 
and communications. The functional group: defense spending means financing the costs of civil defense (in case of emergency events) and military registration.

The specific weight of expenditures for official transfers is quite high: the withdrawal of funds from local budgets for transfer to a higher budget (in this case, the republican budget). Budgetary exemptions are made in areas that, due to a higher economic level of development or by natural conditions, have a tax base higher than the national average and, accordingly, a higher level of tax revenue. Both subventions and withdrawals are used to equalize the level of socio-economic development of administrative-territorial units.

As for the share of expenditures of local budgets in the expenditures of the state budget for certain functional groups, it occupies a predominant place in the areas of financing of the social infrastructure, for example: housing and communal services $-98.8 \%$; healthcare - $100 \%$; education $-99.9 \%$; culture, sport, information space - $97.3 \%$; transport and communication $-99.8 \%$. Quite significant amounts of expenditure are for other groups: financing of the economy as a whole $-46.4 \%$; management (public services of a general nature) $-98.9 \%$; public order and security $-99.3 \%$.

In local budget revenues, local taxes, fees and penalties, deductions from republican taxes in accordance with the standards established by the legislation of the Republic of Kazakhstan, fixed on a long-term basis, are transferred to local governments for the implementation of certain state powers. Also, receipts from privatization of property, from the leasing of municipal property, from local loans and lotteries, part of the profits of local regional enterprises, institutions and organizations, subsidies, subventions, transfer payments, and other income in accordance with the law and decisions of local government are also credited.

Although, on average, transfers from the republican budget account for about $14 \%$ of revenues, in the budgets of some sub-provincial areas this source takes up to $50 \%$, since its own tax and other revenues are not enough to achieve an acceptable level of financing of socio-economic needs. This is due to the fact that in these areas there is a narrow tax base, represented by low-performing economic entities, whose fiscal potential is not large [12].

In this aspect, the problem of redistribution of revenues through the republican budget through the mechanism of budgetary exemptions and subventions is urgent, that is, it is required to develop this mechanism on an objective basis.

Currently, the problems of local budgets in Kazakhstan also consist in the fact that the branches of the economy that make up their property not only do not generate revenues for the formation of budgets (housing, cultural and art institutions, communal infrastructure water supply, transportation, and cleaning services), but are unprofitable and absorb a significant part of local budgets. When the property was divided into the republican and municipal property, unprofitable enterprises or small incomes were transferred to the local authorities.

The composition and structure of income and expenditure of funds at the local level depend on the factors determining the degree of socio-economic development of the administrative-territorial unit: the availability of production facilities, natural resources, social and household infrastructure facilities, unit status, population density, natural and climatic conditions and so on.

The regional representative bodies approve stable rates of income distribution between the regional budget and the budgets of districts and cities, as well as the long-term amounts of subventions transferred from the regional budgets to the budgets of districts and cities and budgetary exemptions transferred from the budgets of districts and cities to the regional budgets.

Budgets are formed on the basis of local budget programs, which are developed by local representative bodies. The financial justification and implementation of local budget 
programs are entrusted to administrators of local budget programs, local executive bodies and state institutions subordinate to them.

Among the important tasks of the State Revenue Committee of the Ministry of Finance of the Republic of Kazakhstan is the improvement of Kazakhstan's position in the World Bank's "Doing Business" rating.

The "Doing Business" rating, which is an objective external evaluation of the Government's actions in improving the country's business climate, is conducted annually by the World Bank in most countries of the world with 11 indicators. Thus, in the "Doing Business" ranking of the World Bank, according to the indicator "Taxation", Kazakhstan ranks 60th among 190 countries (by the results of 2016 - 57th place, decreasing by 3 positions. The reason for the decrease is the change in the methodology of the study. To the three indicators of the indicator "Taxation" (time 178, the rate of $29.2 \%$ and the number of payments 7), an absolutely new index "Postfiring index" was added. According to the dynamics of changes, Kazakhstan, on the indicator "Taxation", previously held very good positions in the rating [13].

The structure of receipts and expenditure of means at the local level depend on the factors defining extent of social and economic development of administrative and territorial unit: existence of production objects, natural resources, objects of social and household infrastructure, status of unit, population density, climatic conditions, etc.

Regional representative bodies approve stable standards of distribution of the income between the regional budget and budgets of areas, cities, and also the long-term sizes of the subventions transferred from regional budgets to budgets of the areas and cities and the budgetary withdrawals transferred from budgets of areas and cities to regional budgets.

Budgeting is carried out on the basis of local budgetary programs which are developed by local representative bodies. Financial justification and implementation of local budgetary programs are assigned to administrators of local budgetary programs, local executive bodies and public institutions subordinated to them.

In the conditions of forming a new control system of market economy, the special value has defining levers and incentives for increasing effective management of budgets at the regional and local level. The considerable part of budget problems is connected with the accuracy of forecasts of its revenues. As practice of regional budgeting shows, applied methods and approaches do not guarantee adequately objective forecasting of the forthcoming receipts in local budgets and are connected with the high level of uncertainty that leads to adoption of incorrect administrative and financial decisions.

As in the theory, and practice too, to developments of the mechanism of the budgetary forecasting as the most important element of financial management, in our country unfairly it is a little given attention. As confirmation to it can serve the fact of lack of uniform approaches to assessment of profitable opportunities of municipalities while in the conditions of strengthening role of local governing bodies and regulation of various aspects socially, economic life of Kazakhstan, value of objective estimates of their profitable opportunities and financial self-sufficiency significantly increases.

Now financial resources of local budgets are predicted on the basis of extrapolation of retrospective data on the tax revenues collected by local bodies for the basic period with the adjustment on indexes - deflators, without profitable opportunities of territories. Within such an approach, territorial authorities are interested not so much in increase of collecting of taxes how many in concealment of tax base. Therefore, similar practice does not promote interest in mobilization of the income in local budgets and loading on the budgetary regulation is more assigned to transfers from the higher budget.

Therefore, forecasting of the income of local budgets demands improvement as in methodologies, techniques, and indicators of tax potential and collecting taxes, have to become fundamental instruments of budgetary and tax planning. 
I believe that the income of local budgets can be most precisely predicted by means of assessment of tax potential. For increasing efficiency of tax planning and improvement of the interbudgetary relations, it is essentially important to provide:

- A uniform approach and system of indicators when planning the income of local budgets;

- Distribution of means of financial aid between territorial educations on the basis of the tax capacity of each territory;

- Creation of motives for developing the tax base of regions and areas.

Proceeding from it, we have made attempt of developing technique of the forecast of profitable opportunities of local budgets on the basis of indicator of the tax potential considering the level and structure of economic development of the territory.

The recommended technique formalizes the process of the budgetary forecasting, that is relies on use of the indicators which are objectively measuring profitable opportunities of local territories on the basis of tax bases with use of certain formula. And the income of local budgets is determined not by the actual receipts for previous years at the developed collecting level, and depending on the size of tax bases [14].

\section{Conclusion}

Improving Kazakhstan's position in the World Bank's "Doing Business" rating is a priority task of the state, which is based on the instruction of the Head of State on Kazakhstan's entry into the list of the 30 developed countries of the world.

In connection with taking into account the goals set by the Head of State in the Message to the People of Kazakhstan "The Third Modernization of Kazakhstan: Global Competitiveness," the main priorities for spending the budget until 2018 are:

- Increasing the employment of the population.

- Providing the population with affordable housing.

- Regional development.

- Qualitative growth of human capital.

- Improving the living conditions of the population.

- Industrial and innovative development [15].

One of the most important priorities of budgetary expenditures will be implementing the state's social obligations in full. In the context of the slowdown in the world economy and low commodity prices, the country's budget policy is aimed at preserving the sustainability of public finances, tight budget savings, and improving the efficiency of public spending.

Thus, summing up the results of the study, we can conclude that the level of tax revenues and the tax potential of the region significantly affect the opportunities and quality of economic growth in the region. Therefore, the formation of budgets of all levels should be based on a scientific forecast of the revenue side of the budget, based on economic realities and objective economic laws.

\section{References}

1. L. K. Ayusheva, Social and economic development of regions: problems, prospects, $\mathbf{1}$ (2015)

2. K. B. Bleutayeva, Vestnik KEU, 3 (2015)

3. S. M. Omirbayev, State budget (Economics, Almaty, 2011)

4. Ministry of Finance of the Republic of Kazakhstan, Execution of the State Budget of $R K$ for 2013-2016 (www.minfin.kz, 2017) 
5. General declaring of the income and property in Kazakhstan is planned to be entered by 2017 (www.tengrinews.kz, 2016)

6. N. A. Nazarbayev, Message of the President of Kazakhstan N. A. Nazarbayev to the people of Kazakhstan Strategy "Kazakhstan - 2050: New political policy of the taken place state" (2012)

7. Tax revenues in the budget of Kazakhstan (www.ranking.kz/, 2016)

8. O. Elanchuk, Problems of the Theory and Practice of Management, 2 (2010)

9. Turkish system of the taxation (http://infoturk.biz/uslugi/nalogooblojenie.html, 2016)

10. D. Ye. Fadeyev, Nalogoviy Vestnik, 5 (2015)

11. The report of the akim of the Aktyubinsk region for 2016 (Актобе, 2016)

12. S. Abdrakhmanov, Comparative analysis of income and expenses of local budgets for 2008 - 2014 (Astana, 2014)

13. Doing Business indicators which are within the competence of the Ministry of Finance of the Republic of Kazakhstan (www.kgd.gov.kz, 2016)

14. N. I. Kozlov, News of the Tula State University, 7 (2011)

15. N. A. Nazarbayev, Message of the President of Kazakhstan N. A. Nazarbayev "Third modernization of Kazakhstan: Global competitiveness" (Akorda, 2017) 